\title{
TINGKAT PENGETAHUAN SIKAP DAN TINDAKAN PETANI TENTANG PENGGUNAAN ALAT PELINDUNG DIRI DI SUBAK CEPIK KABUPATEN TABANAN TAHUN 2019
}

\author{
Kadek Nanda Bella Indriana ${ }^{1}$, I Wayan Suarta Asmara ${ }^{2}$, I Gusti Ayu Made Aryasih ${ }^{3}$
}

\begin{abstract}
Farmers are the largest working group in Indonesia. The level of farmers' exposure to the use of pesticides is highly dependent on how knowledge is used in using pesticides. Tabanan Regency is one of the districts in Bali. The area of paddy in Tabanan Regency reaches 22,453 hectares which is the widest rice field area and at the same time as a rice barn in Bali Province. The purpose of this study was to determine the knowledge, attitudes, and actions of farmers in the use of personal protective equipment. The method used is descriptive, primary data obtained through interviews and direct observation using questionnaires and secondary data obtained from the village head in the form of population data. The results of the study revealed that 18 respondents (29\%) had sufficient knowledge and 45 respondents (71\%) had good knowledge. As many as 2 respondents (3\%) who had less attitudes, 36 respondents (57\%) who had enough attitudes, and 25 respondents (40\%) who had good attitudes. And as many as 57 respondents (90\%) who have less action, 6 respondents (10\%) who have enough action. Conclusion in this study farmers have good knowledge, but attitudes and actions to use personal protective equipment when direct contact with pesticides is still lacking.
\end{abstract}

Keywords : Education, Attitudes, Action, Personal Protective Equipment

\section{PENDAHULUAN}

Pestisida adalah substansi kimia dan bahan lain serta jasad renik dan virus yang digunakan untuk mengendalikan berbagai hama. Dimaksud hama disini adalah sangat luas, yaitu serangga, tungau, tumbuhan penggangu, penyakit tanaman yang disebabkan oleh fungi (jamur), bacteria dan virus, kemudian nematoda (bentuknya sepertinya cacing dengan ukuran microskopis, siput, tikus, burung dan hewan lain yang dianggap merugikan.(1).

\section{Menurut data World Health}

Organization (WHO)(2), penggunaan

pestisida semakin lama semakin tinggi, terutama negara-negara berkembang seperti di asia, afrika, amerika tengah dan amerika latin, tetapi negara-negara 
berkembang ini hanya menggunakan $25 \%$ dari total penggunaan pestisida di seluruh dunia. Walaupun negaranegara ini hanya menggunakan $25 \%$, tetapi dalam hal kematian akibat pestisida, 99\% dialami oleh negaranegara diwilayah tersebut

Hal ini disebabkan rendahnya tingkat edukasi petani-petani dinegaranegara tersebut sehingga cara penggunaannya sangat tidak aman. Data dari Program Lingkungan Perserikatan Bangsa-Bangsa (PBB) memperkirakan akan 3 juta orang yang bekerja pada sector pertanian di negara-negara berkembang terkena racun pestisida dan sekitar 18.000 orang diantaranya meninggal setiap tahunnya. (3).

Tingkat keterpaparan petani dalam penggunaan pestisida sangat tergantung bagaimana pengetahuan dalam menggunakan pestisida (4) Teknik penyemprotan yang kadang melawan arah mata angin, menyebabkan petani menghirup pestisida tanpa disadarinya. Perilaku penggunaan pestisida yang berlebihan seperti itu justru menimbulkan masalah baru yakni adanya residu pestisida pada produk pertanian dan pada akhirnya membahayakan petani dan masyarakat luas baik keselamatan maupun kesehatan kerjanya. (3).

Kabupaten Tabanan merupakan bagian dari salah satu kabupaten di Bali. Luas sawah di Kabupaten Tabanan mencapai luas 22.453 hektar yang merupakan wilayah sawah yang terluas dan sekaligus sebagai lumbung padi di Provinsi Bali. Kabupaten Tabanan memiliki 228 Subak yang tersebar, dimana setiap subak yang ada tersebut diberi otonomi dalam mengatur anggota subak yang telah disepakati secara bersama dalam bentuk aturan tertulis atau awigawig.(5).

Berdasarkan survey yang dilakukan pada petani di Subak Cepik, Desa Tajen, Kabupaten Tabanan, dalam melakukan kegiatan kerja yakni penyemprotan pestisida petani tidak menggunakan alat pelindung diri. Terkadang dalam melakukan kegiatan penyemprotan pestisida petani hanya menggunakan penutup kepala (topi) saja, dan terdapat sebagian petani dalam mencampur pestisida tanpa menggunakan sarung tangan bahkan 
ada yang merokok dalam melakukan aktivitasnya.

Setelah melakukan kegiatan penyemprotan pestisida petani pernah merasakan panas dikulit wajah, mata merah dan perih, mengalami gatal dan iritasi, dan sesak nafas. Petani juga mengatakan mereka tidak membaca aturan penggunaan pestisida dengan baik, dan tidak mengetahui secara jelas tentang alat pelindung diri. Petani kurang mendapatkan informasi mengenai Penggunaan alat pelindung diri dalam melakukan penyemprotan baik informasi dari media ataupun penyuluhan-penyuluhan petugas kesehatan

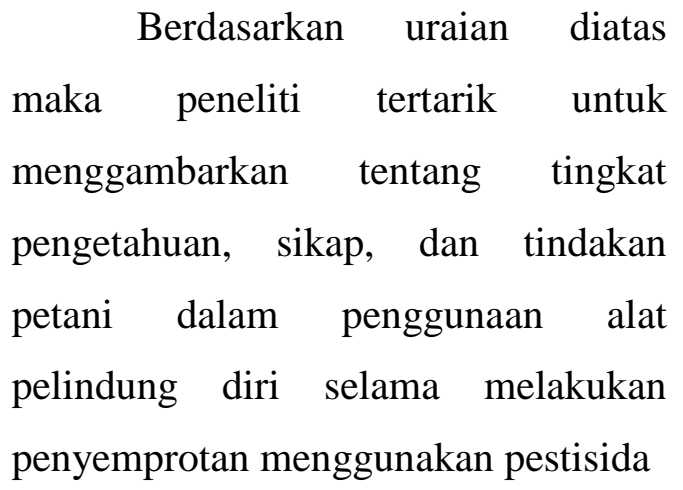

Adapun tujuan dalam penelitian ini adalah (1) Untuk mengetahui pengetahuan petani tentang penggunaan alat pelindung diri pada kegiatan penyemprotan pestisida di Subak Cepik, Desa Tajen,
Kabupaten Tabanan, (2) Untuk mengetahui sikap petani tentang penggunaan alat pelindung diri pada kegiatan penyemprotan pestisida di Subak Cepik, Desa Tajen, Kabupaten Tabanan, (3) Untuk mengetahui tindakan petani tentang penggunaan alat pelindung diri pada kegiatan penyemprotan di Subak Cepik, Desa Tajen, Kabupaten.

\section{METODE}

Desain dalam penelitian ini adalah penelitian deskriptif.(6). Metode pendekatan yang digunakan dalam penelitian ini adalah cross sectional. Cross sectional yaitu pendekatan yang menekankan pada waktu pengukuran atau observasi data variable hanya satu kali saja, pada suatu saat.jadi tidak ada follow up. (7) Dalam penelitian ini penulis mendeskripsikan pengetahuan, sikap dan tindakan petani melalui pengkategorian baik, cukup, kurang. Populasi dalam penelitian ini adalah petani penggarap yang berjumlah 93 orang dan petani tetap yang berjumlah 77 orang dengan total 170 orang petani di Subak Cepik, Desa Tajen, Kabupaten Tabanan. 
Data primer yang diperoleh yaitu identitas responden, tingkat pengetahuan, sikap, dan tindakan petani dalam penggunaan alat pelindung diri di Subak Cepik, Desa Tajen, Kabupaten Tabanan Tahun 2019. Data sekunder yang digunakan dalam penelitian ini adalah data yang di dapatkan dari klian Subak Cepik mengenai profil lengkap, gambaran umum, jumlah petani dan segala informasi Subak Cepik, Desa Tajen, Kabupaten Tabanan Tahun 2019.

Teknik pengumpulan data adalah observasi dan wawancara. Observasi yang dilakukan adalah pengamatan langsung dilapangan dengan melihat tindakan petani dalam penggunaan alat pelindung diri. Wawancara atau interview yang dipergunakan yaitu face to face menggunakan kuesioner dengan petani, mengenai pengetahuan, sikap dan tindakan petani dalam penggunaan alat pelindung diri.

Analisis data adalah data yang diolah kemudian di analisa secara univariat. Analisa dilakukan terhadap semua variable penelitian berupa jawaban dari responden. Analisa ini menghasilkan distribusi dari data setiap variable seperti tingkat pengetahuan, sikap, dan tindakan terhadap pemakaian alat pelindung diri yang pada umumnya analisa ini hanya menghasilkan distribusi dan presentase dari setiap variable. (8).

Dengan rumus : $P=\frac{\mathrm{f}}{\mathrm{n}} \times 100$

$\mathrm{P}=$ persentase $(\%)$

$\mathrm{f}=$ frekuensi yang di dapat

$\mathrm{n}=$ jumlah sampel yang digunakan

\section{HASIL DAN PEMBAHASAN}

1. Gambaran lokasi penelitian

Penelitian dilakukan di Subak Cepik, Banjar Cepik, Desa Tajen. Desa Tajen merupakan salah satu desa yang terletak diwilayah Kecamatan Penebel, Kabupaten Tabanan Desa Tajen terletak $\pm 6 \mathrm{~km}$ kearah utara dari pusat kota Tabanan. Subak cepik terletak di Banjar Cepik, Desa Tajen. Subak cepik terdiri dari 5 tempek (bagian wilayah) yaitu Tempek Bungbung Belah, Tempek Lanyan, Tempek Saren, Tempek Desa, dan Tempek Babakan. Subak Cepik mempunyai jumlah petani yaitu 170 orang dengan luas persawahan 80,00 Ha. 
2. Daftar pestisida yang digunakan petani

\begin{tabular}{|c|c|c|}
\hline No & $\begin{array}{c}\text { Nama } \\
\text { Bahan } \\
\text { Aktif }\end{array}$ & $\begin{array}{c}\text { Bidang } \\
\text { Penggunaan }\end{array}$ \\
\hline 1. & $\begin{array}{l}\text { Parakuat } \\
\text { diklorida }\end{array}$ & $\begin{array}{l}\text { Pengelolaan } \\
\text { tamanan, contoh } \\
\text { dengan merk } \\
\text { dagang } \\
\text { Gramoxone } 276 \\
\text { SL, Kresnaxone } \\
\text { 297 SL }\end{array}$ \\
\hline 2. & $\begin{array}{l}\text { Aluminium } \\
\text { fosfida }\end{array}$ & $\begin{array}{l}\text { Pra panen hasil } \\
\text { pertanian, } \\
\text { contoh merk } \\
\text { dagang Alphos } \\
57 \text { TB, } \\
\text { Quickphos } 56 \mathrm{P}, \\
\text { Match 50 EC, } \\
\text { Magnaphos, } \\
\text { Magtoxin 56 PB, } \\
\text { Fumigrad } 99 \mathrm{GA}\end{array}$ \\
\hline
\end{tabular}

3. Karakteristik responden

Karakteristik Petani Berdasarkan Jenis Kelamin. Petani berjenis kelamin laki-laki sebanyak 52 petani $(83 \%)$ dan petani berjenis kelamin perempuan sebanyak 11 petani $(17 \%)$.

\begin{tabular}{cccc}
\hline No & $\begin{array}{c}\text { Jenis } \\
\text { Kelamin }\end{array}$ & Frekuensi & $\%$ \\
\hline 1 & Laki - laki & 52 & 83 \\
2 & Perempuan & 11 & 17 \\
\hline & Jumlah & 63 & 100 \\
\hline
\end{tabular}

Karakteristik

Petani Berdasarkan Usia. Petani berusia 45 55 tahun sebanyak 24 petani (38\%), usia petani 56 - 66 tahun sebanyak 21 petani (33\%), dan usia petani 67-77 tahun sebanyak 18 petani $(29 \%)$.

\begin{tabular}{rccc}
\hline No & Usia & Frekuensi & $\%$ \\
\hline 1 & $45-$ & 24 & 38
\end{tabular}
55

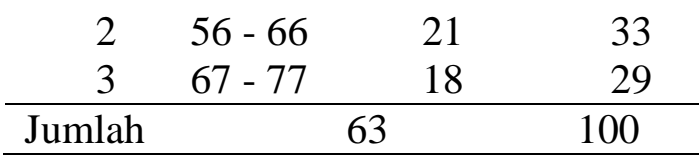

Karakteristik

Petani Berdasarkan Tingkat Pendidikan . Tingkat pendidikan petani mulai dari Tidak Sekolah (TS) sebanyak 12 petani (19\%), mengikuti sampai tingkat Sekolah Dasar (SD) sebanyak 19 petani (30\%), mengikuti sampai tingkat Sekolah Menengah Pertama 63 (SMP) sebanyak 22 petani $(35 \%)$, dan mengikuti sampai tingkat Sekolah Menengah Atas (SMA) sebanyak 10 petani $(16 \%)$. 


\begin{tabular}{cccc}
\hline No & $\begin{array}{c}\text { Tingkat } \\
\text { Pendidikan }\end{array}$ & Frekuensi & $\%$ \\
\hline 1. & Tidak & 12 & 19 \\
& $\begin{array}{c}\text { Sekolah } \\
\text { (TS) }\end{array}$ & & \\
2. & SD & 19 & 30 \\
3. & SMP & 22 & 35 \\
4. & SMA & 10 & 16 \\
\hline \multicolumn{2}{c}{ JUMLAH } & 63 & 100 \\
\hline
\end{tabular}

4. Hasil Penelitian

Distribusi Petani Berdasarkan Pengetahuan Tentang Alat Pelindung Diri (APD) Di Subak Cepik Desa Tajen Kabupaten Tabanan Tahun 2019. Didapat hasil 45 petani $(71 \%)$ yang mempunyai pengetahuan baik, 18 petani (29\%) yang mempunyai pengetahuan cukup

\begin{tabular}{ccc}
\hline Pengetahuan & Frekuensi & $\%$ \\
\hline Baik & 45 & 71 \\
Cukup & 18 & 29 \\
Kurang & 0 & 0 \\
\hline Jumlah & 63 & 100 \\
\hline
\end{tabular}

Pengukuran pengetahuan dalam penelitian ini, yakni dengan mengukur pengetahuan petani tentang pengertian alat pelindung diri, manfaat alat pelindung diri, dan akibat tidak menggunakan alat pelindung diri, yang diperoleh melalui jawaban atas pertayaan responden pada kuesioner. Berdasarkan hasil penelitian tingkat pengetahuan yang dibagi dalam tiga kategori yaitu kurang, cukup, baik.

Berdasarkan hasil penelitian ini menunjukan bahwa dari 63 petani memiliki pengetahuan baik sebanyak 45 petani $(71 \%), 18$ petani $(29 \%)$ cukup.

Pada umumnya tingkat pengetahuan berkaitan dengan tingkat pendidikan namun berdasarkan hasil yang didapat, tingkat pendidikan terbanyak yaitu SMP sedangkan hasil tingkat pengetahuan terbanyak yaitu kategori baik. Hal ini dipengaruhi oleh beberapa petani sudah paham tentang penggunaan alat pelindung diri.

Distribusi Petani Berdasarkan Sikap Tentang Alat Pelindung Diri (APD) Di Subak Cepik Desa Tajen Kabupaten Tabanan Tahun 2019. Didapat hasil 36 petani (57\%) yang mempunyai pengetahuan cukup, 25 petani (40\%) yang mempunyai sikap baik, dan 2 petani (3\%) mempunyai pengetahuan kurang. 


\begin{tabular}{ccc}
\hline Sikap & Frekuensi & $\%$ \\
\hline Baik & 25 & 40 \\
Cukup & 36 & 57 \\
Kurang & 2 & 3 \\
\hline Jumlah & 63 & 100 \\
\hline
\end{tabular}

Berdasarkan hasil penelitian menunjukan bahwa sikap petani dalam penggunaan alat pelindung diri terdapat 36 petani $(57 \%)$ memiliki sikap cukup, 2 petani (3\%) memiliki sikap kurang dan hanya 25 petani (40\%) memiliki sikap yang baik.

Petani dalam penelitian ini sebagian besar memiliki sikap cukup, sehingga membawa responden untuk tidak memakai alat pelindung diri, hal ini dipengaruhi karena ketidaknyamanan petani dalam pemakaian alat pelindung diri.

Untuk terwujudnya sikap menjadi suatu perbuatan nyata diperlukan faktor pendukung atau suatu kondisi yang memungkinkan, antara lain adalah fasilitas. Disamping fasilitas juga diperlukan dukungan (support) dari pihak lain, misalnya keluarga dalam mendukung memakai alat pelindung diri lengkap(9)

Distribusi Petani Berdasarkan Tindakan Tentang Alat Pelindung Diri
(APD) Di Subak Cepik Desa Tajen Kabupaten Tabanan Tahun 2019. Didapat d6 petani (10\%) yang mempunyai pengetahuan cukup dan 57 petani $(90 \%)$ mempunyai pengetahuan kurang.

\begin{tabular}{ccc}
\hline Tindakan & Frekuensi & $\%$ \\
\hline Baik & 0 & 0 \\
Cukup & 6 & 10 \\
Kurang & 57 & 90 \\
\hline Jumlah & 63 & 100 \\
\hline
\end{tabular}

Tindakan adalah suatu usaha atau perbuatan yang dilakukan oleh seseorang dalam keadaansadar. Berdasarkan hasil penelitian menunjukan bahwa tindakan petani dalam penggunaan alat pelindung diri terdapat 57 petani $(90 \%)$ memiliki tindakan yang kurang, dan 6 petani (10\%) memiliki tindakan cukup. Secara umum tindakan petani dalam pemakaian alat pelindung dirisangat kurang.

Pengaruh residu pestisida terhadap kesehatan manusia adalah dapat mengganggu metabolisme steroid, merusak fungsi tiroid, berpengaruh terhadap spermatogenesis, terganggu system 
hormone endokrin (hormone reproduksi) atau yang lebh dikenal dengan istilah EDs (Endocrine Disrupting Pesticides), disamping dapat merangsang timbulnya kanker, gejala keracunan akut pada manusia adalah paraestesia, tremor, sakit kepala, keletihan dan muntah. Efek keracunan kronis pada manusia adalah keracunan sel-sel hati, ginjal, system saraf, system imunitas dan system reproduksi. (10)

Pestisida yang digunakan para petani yaitu pestisida yang mengandung chemical organofosfat seperti Parakuat diklorida digunakan untuk pengelolaan tanaman dengan merk dagang Gramoxone 276 SL,Kresnaxone 297 SL, Pospit 80 P, dan Genquat 240 SL. Aluminium fosfida digunakan pada pra-panen hasil pertanian dengan merk dagang Alphos 57 TB, Qouickphos 56 P, Match 50 EC, Magnaphos,Magtoxin 56 PB, dan Fumigard 99 GA. Dampak dari penggunaan pestisida tersebut terhadap kesehatan petani seperti petani merasakan panas dikulit, mata merah dan perih, mengalami gatal dan iritasi serta batuk-batuk, muntah dan pusing.
Maka hendaknya perlu dilakukan penyuluhan kesehatan dan keselamatan kerja pada petani serta melakukan pengawasan penggunaan alat pelindung diri, dan melakukan pemeriksaan cholinesterase terhadap petani karena apabila kholinestrase terikat, maka enzim tersebut tidak dapat melaksanakan tugasnya sehingga syaraf dalam tubuh terus menerus mengirimkan perintah kepada otototot tertentu (11).

\section{SIMPULAN DAN SARAN}

Simpulan

Dari pembahasan hasil pengamatan yang dilakukan petani pada saat menggunakan alat pelindung diri dalam melakukan kegiatan penyemprotan pestisida di Subak Cepik, Desa Tajen, Kecamatan Penebel, Kabupaten Tabanan, maka penulis mengambil kesimpulan sebagai berikut :

1. Sebanyak (29\%) petani yang mempunyai pengetahuan dengan kategori cukup, dan (71\%) petani yang mempunyai pengetahuan dengan katagori baik dalam penggunaan alat pelindung diri 
pada saat melakukan kegiatan penyemprotan pestisida.

2. Sebanyak (3\%) petani yang mempunyai sikap dengan kategori kurang, 36 (57\%) petani yang mempunyai sikap dengan kategori cukup, dan (40\%) petani yang mempunyai sikap dengan kategori baik dalam penggunaan alat pelindung diri pada saatmelakukan kegiatan penyemprotan pestisida.

3. Sebanyak (90\%) petani yang mempunyai tindakan dengan kategori kurang, (10\%) petani yang mempunyai tindakan dengan kategori cukup, dalam penggunaan alat pelindung diri pada saat melakukan kegiatan penyemprotan pestisida.

Saran.

Berdasarkan kesimpulan yang diperoleh, maka penulis menyarankan

1. Bagi petani

a. Diharapkan menggunakan alat pelindung diri dengan lengkap pada saat kontak langsung dengan pestisida. b. Perlu dilakukan pemeriksaan cholinesterase pada darah petani.

2. Bagi pemerintah

Perlu diingatkan kepada dinas terkait hendaknya melakukan penyuluhan tentang penggunaan alat pelindung diri pada saat kontak langsung dengan pestisida supaya menambah pengetahuan dan mengubah prilaku petani yang buruk menjadi lebih baik terutama dalam menggunakan alat pelindung diri.

3. Bagi peneliti selanjutnya

Perlu adanya penelitian yang lebih lanjut misalnya dengan 1menghubungkan perilaku petani terhadap keracunan akibat pestisida tersebut.

\section{DAFTAR PUSTAKA}

1. Biotis Agrindo. Pestisida. 2015;

2. WHO. Organophosphorus

Isecticida, A General

Introduction Environmental

Health Criteria WHO Geneva.

2007;

3. Departemen Kesehatan.

Pedoman pengamanan

penggunaan pestisida khusus 
untuk petani dan operator

pestisida. 2003;

4. Djojosumarto. Teknik Aplikasi

Pestisida Pertanian. 2008;

5. Sutopo. sistem kelembaban subak sebagai warisan budaya dunia. 2013.

6. Arikunto. Metodelogi Penelitian, Jakarta. 2014;

7. Nursalam. Konsep dan penerapan metodelogi penelitian ilmu kesehatan. Salemba Medika; 2013.
8. Notoatmodjo. Promosi kesehatan dan perilaku kesehatan. jakarta: Rineka Cipta; 2010.

9. PK. S. Hiperkes Keselamatan Kerja dan Ergonomi. Dharma Bakti Muara Agung. Jakarta. 1994;

10. Anonim. Dampak Penggunaan Pestisida. 2014;

11. Tarwaka. Keselamatan dan Kesehatan Kerja. 2008; 